Chapter 2

\title{
Cotton (Gossypium hirsutum L.) Response to Pendimethalin Formulation, Timing, and Method of Application
}

\author{
Timothy Grey and Theodore Webster
}

Additional information is available at the end of the chapter

http://dx.doi.org/10.5772/56184

\section{Introduction}

The introduction of glyphosate-resistant cotton for production in the southeast United States changed herbicide application strategies and increased the profitability of no-tillage and striptillage techniques. Glyphosate ( $N$-[phosphonomethyl]-glycine) is a highly effective herbicide that controls a broad spectrum of annual and perennial grass and broadleaf weeds in cotton $[3,37]$. When glyphosate-resistant cotton varieties were first introduced, glyphosate was applied two to four times on most fields and may have been the only herbicide used $[4,5]$. In Georgia, 93\% of the cotton acres received at least one glyphosate application in 2005 [3]. The technology allowed growers to reduce or eliminate soil-applied herbicides, allowing them to abandon cultivation and make the transition to conservation tillage, which promotes soil conservation and compliance with USDA Federal regulations. Greater than 50\% of Georgia cotton was produced using no-tillage or strip-tillage techniques in 2007, a strategy that has been affected by glyphosate weed control [1, 11].

\section{Importance}

With the elimination of cultivation as a control tactic in conservation tillage systems, herbicides were the primary and often only method used for weed control [24]. However, the incidence of herbicide-tolerant or resistant weeds emerging in the southeast United States [33, 34] has increased the need for multiple herbicide modes of action in both conservation tillage and conventional tillage weed management systems $[3,5,16]$. In Georgia, there are populations of Palmer amaranth (Amaranthus palmeri S. Wats.) (Figure 1) with resistance to glyphosate, ALS, 
triazines, dinitroanilines, with some populations demonstrating resistance to multiple mechanisms of action [5, 26, 31, 38]. While glyphosate- and ALS-resistant Palmer amaranth is widespread in Georgia, the frequency and distribution of triazine- and dinitroaniline-resistant has not been characterized in Georgia. With the potential mobility of herbicide resistance traits, through movement of pollen [27, 28] or seed [18] and/or potentially high levels of naturally occurring mutations conferring resistance, cotton production in the region is threatened by herbicide resistant weeds.

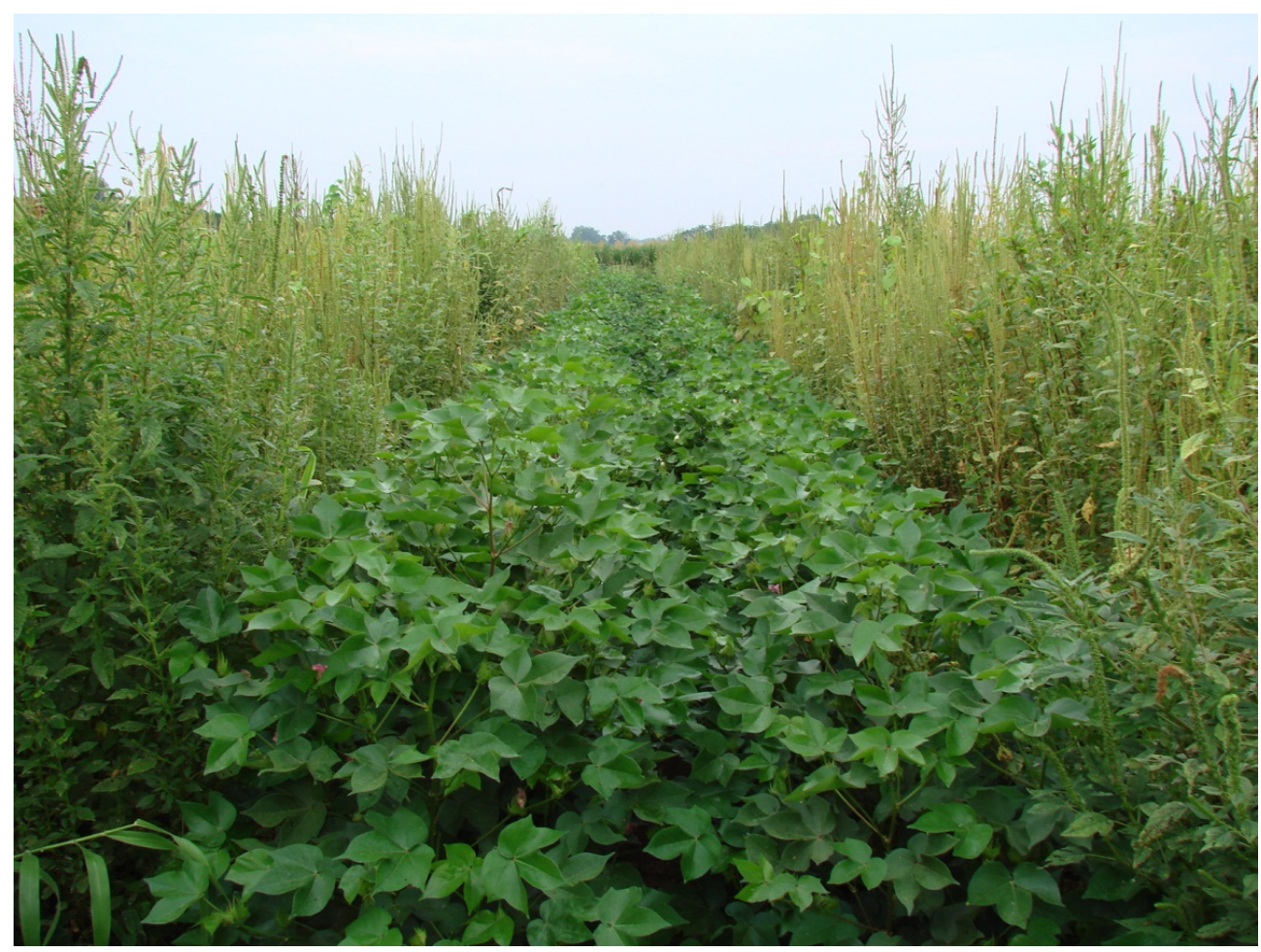

Figure 1. Glyphosate resistant Palmer amaranth in conventional upland cotton in Georgia.

The increased occurrence of herbicide-resistant weeds necessitates the search for alternative control tactics. For instance, metolachlor had not been traditionally used in cotton because of excessive crop injury when applied preemergence after planting. However, changing its use pattern to be applied after cotton emergence avoided crop injury, while controlling an exotic weed that had become troublesome [4]. This technology and new mechanism of action has been instrumental in current management of glyphosate-resistant Palmer amaranth. Research on a new use pattern for pendimethalin may provide an additional tool for weed management at different times in the growing season. 


\section{Background information on soil applied herbicides}

Herbicides with soil persistence and weed control activity were extensively used for preemergence weed control in cotton until the commercial release of herbicide-resistant cotton in 1997. Cotton herbicides with soil residual properties included cyanazine (2-((4-chloro-6(ethylamino)-1,3,5-triazin-2-yl]amino]-2-methylpropanenitrile), diuron ( $N$ '-(3,4-dichlorophenyl)- $N, N$-dimethylurea), flumeturon ( $N, N$-dimethyl- $N^{\prime}$ (3-(trifluoromethyl)phenyl]urea), pendimethalin (N-(1-ethylpropyl)-3,4-dimethyl-2,6-dinitrobenzenamine), trifluralin (2,6dinitro-N,N-dipropyl-4-(trifluoromethyl(benzenamine), and others. Pendimethalin was registered for cotton in 1975 [22]. These herbicides were applied pre-plant soil incorporated (PPI), pre-emergence (before cotton and weed emergence) and/or post-directed (where applications are directed to the soil and bottom portion of the stems of mature cotton plants). Cotton in the southeastern U.S. has a growing season that can extend to over 150 days ranging from late March to early November. Growers can PRE apply pendimethalin but have to PPI trifluralin. This allows conservation tillage cotton growers an option to use a dinitroaniline herbicide for grass and small seeded broadleaf weed control. A weakness in weed efficacy of these residual herbicides was the lack of extended weed control due to dissipation of the herbicide in the soil. With the introduction and high rate of adoption of glyphosate-resistant cotton varieties and almost exclusive use of glyphosate for weed control, the herbicides with soil residual activity was reduced in favor of total post-emergence weed control programs. The cotton registration for cyanazine was eventually canceled in 2002 in the United States. However, even with increased herbicide-resistant weeds in growers' fields in the first decade of the 2000's, diruon, flumeturon, and pendimethalin use did not increase, even though residual herbicides could improve weed control (Figure 2). Diuron and flumeturon are widely applied to cotton as post-directed sprays in this region. However, growers using conservation tillage practices in cotton often rely on pendimethalin for early season residual weed control with preemergence applications either sprayed or impregnated on fertilizers.

\subsection{Pendimethalin}

Pendimethalin is a member of the dinitroanaline family of herbicides. Pendimethalin prevents plant cell growth by inhibiting spindle formation during cell division [6]. Pendimethalin is applied PRE to the soil surface, with or without incorporation into the soil, to approximately $37 \%$ of Georgia cotton [17] for control of grasses and small-seeded broadleaf weed species [2]. Pendimethalin inhibits mitotic cell division in susceptible plants [30], while tolerant crops grow through, or are planted below, the treated zone [13, 14]. Among the dinitroanaline herbicides, pendimethalin has greater water solubility of $0.275 \mathrm{ug} \mathrm{mL}^{-1}$ and less volatility at $9.4 \times 10^{-6} \mathrm{~mm}$ $\mathrm{Hg}$ at $25 \mathrm{C}$ [22], allowing it to be applied to the soil surface rather than needing mechanical incorporation $[35,36]$. However, pendimethalin still requires moisture in the form of rainfall or irrigation in order to move it into the active zone of weed germination. Cotton selectivity of pendimethalin pre-emergence is due to differences in metabolism and sequestration of pendimethalin in the lysigenous glands [25]. Pendimethalin is registered for PRE application up to 2 days after cotton planting. However, delayed application in combination with excessive moisture (rainfall or irrigation) can result in injury to seedling cotton. Pendimethalin injury to 


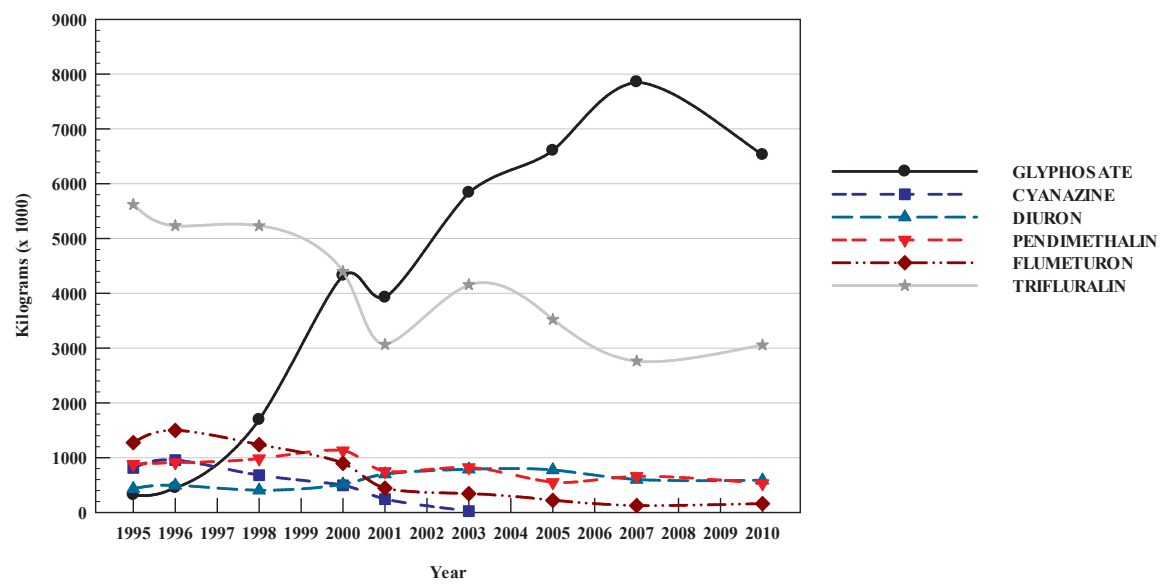

Figure 2. Residual cotton herbicides use as compared to glyphosate in United States cotton production since the advent of glyphosate resistant cotton [17].

cotton seedlings results in delayed hypocotyl development and can also cause abnormal root growth. This injury is commonly associated with enlarged lower stems and 'bottle brush' root development. Microbial decomposition is the main method of pendimethalin dissipation [19, 32]. While pendimethalin has a reported soil half-life of 74 to 114 days [30], surface applied half-lives of 4 to 6 days can occur due to volatilization, photo-chemical, and other degradation processes [21]. Additionally, increased degradation can occur with no-tillage application [9].

\subsection{Pendimethalin weed control}

Pendimethalin is often used in cotton to supplement control of grass weeds and small-seeded broadleaf weed species. According to the University of Georgia Extension recommendations, pendimethalin provides excellent (90\%) control of crabgrass (Digitaria sanguinalis (L.) Scop.), crowfootgrass (Dactyloctenium aegyptium (L.) Willd.), foxtails (Setaria species), goosegrass (Eleusine indica (L.) Gaertn.), seedling johnsongrass (Sorghum halepense (L.) Pers.), and sandbur (Cenchrus echinatus L.); good control (80-90\%) of fall panicum (Panicum dichotomiflorum Michx.) and Texas millet (Urochloa texana (Buckl.) R. Webster). Pendimethalin also provides excellent $(90 \%)$ to good (80-90\%) control of the broadleaf species Florida pusley (Richardia scabra L.), pigweeds (Amaranthus species), lambsquarters (Chenopodium album L.), and pink purslane (Portulaca pilosa L.); and fair to good (60-90\%) control of Palmer amaranth.

\subsection{Pendimethalin formulation}

There are two liquid formulations of pendimethalin registered for cotton in the United States. One contains $37.4 \%$ pendimethalin $(0.41 \mathrm{~kg}$ ai/L) formulated with aromatic naphtha as an emulsifiable concentrate (EC), and the other contains $38.7 \%$ pendimethalin $(0.47 \mathrm{~kg}$ ai $/ \mathrm{L})$ 
formulated as a microencapsulated (ME) aqueous capsule suspension [12] (Figure 3). One potential method of obtaining extended weed control to apply pendimethalin as an in-season application, i.e. from emergence to when the cotton crop has up to six leaves, or just prior to canopy formation. However, injury to cotton from the EC formulation has prevented topical applications in the past.

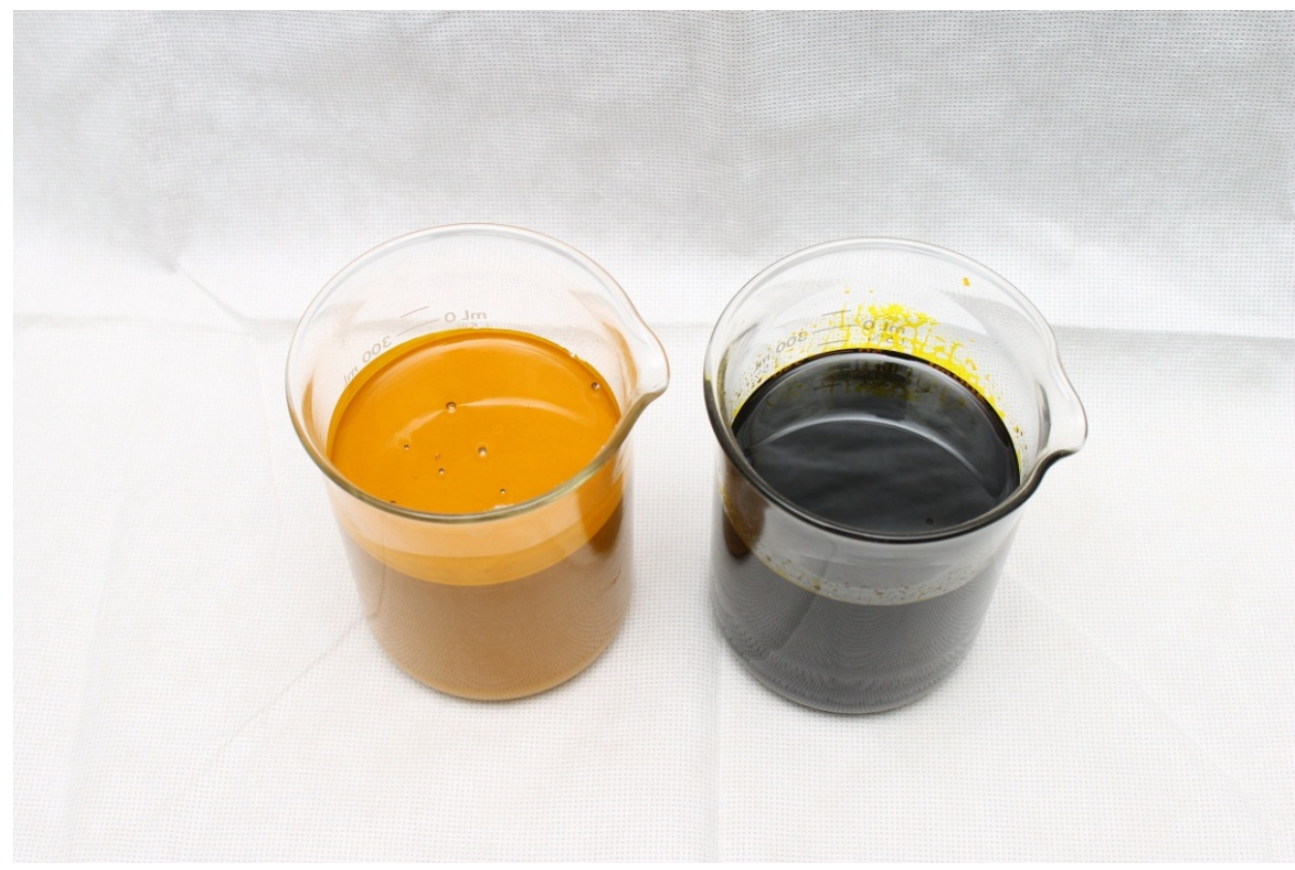

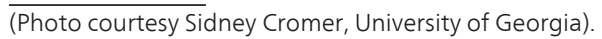

Figure 3. Pendimethalin microencapsulated aqueous capsule suspension (left) and pendimethalin emulsifiable concentrate (right)

\subsection{Research}

Cotton response to pendimethalin ME applied at different growth stages is less injurious to cotton because of its formulation. An alternative method of application is to impregnate pendimethalin onto fertilizer for in-season application to extend residual weed control, reducing the number of herbicide applications [15, 20], and minimizing potential crop injury. Crop injury has been noted with pendimethalin EC and ME when applied topically to cotton at the 4th leaf growth stage [7] and its effects on cotton nutrient uptake [10]. Weed control for comparing pendimethalin EC to ME in cotton have been made using spray applications [11]. Florida pusley and Texas millet control were similar and consistent for PRE applied EC and ME formulations (Table 1). While weed control has been evaluated, cotton crop response to 
applications made PRE up to the $6^{\text {th }}$ leaf growth stage comparing season- long factors is also needed. Therefore, this chapter will emphasize pendimethalin use, formulation (EC and ME), and cotton response. Additionally, this chapter will focus on pendimethalin formulations when applied as an aqueous solution in water or impregnated on fertilizers [15].

\begin{tabular}{llccc}
\hline Formulation & Application method & Timing & Texas millet & Florida pusley \\
\hline Pendimethalin EC & Spray & PRE & 75 & \\
\hline Pendimethalin ME & Spray & PRE & 75 & 66 \\
\hline
\end{tabular}

aAbbreviations: EC, emulsifiable concentrate; ME, microencapsulated; PRE, prior to plant emergence.

Table 1. Weed control in Georgia cotton with pendimethalin $\mathrm{EC}^{\mathrm{a}}$ and $\mathrm{ME}^{\mathrm{a}}$ formulations applied at planting.

\section{Studies}

\subsection{Field studies}

Field trials were conducted in 2005, 2006, and 2007 at the University of Georgia Ponder Research Station near Ty Ty, Georgia. Soil was Tifton loamy sand (fine-loamy, kaolinitic, thermic Plinthic Kandiadults) with $83 \%$ sand, $12 \%$ silt, 5\% clay, organic matter content of 1 to $1.8 \%$, and $\mathrm{pH}$ of 5.6 to 6.1 . Conventional tillage was used during all three years of the study to obtain optimal herbicide/soil contact, since pendimethalin has been observed to adsorb to cover crop residue [9]. Delta and Pineland 555 BG/RR was planted in 2005 and Delta and Pineland Flex 445 BG/RR in 2006 and 2007 using a Monosem precision vacuum planter set to deliver 14 seeds per linear meter of row with $0.9 \mathrm{~m}$ between row centers. The experimental design was a two factor randomized complete block with treatments replicated four times. Plots were $1.8 \mathrm{~m}$ (two rows) wide by $8 \mathrm{~m}$ long. Four different methods of pendimethalin application were made at four different timings during the growing season. All herbicide treatments consisted of $1.1 \mathrm{~kg}$ active ingredient $/ \mathrm{ha}$ of pendimethalin EC or ME. Only the method or time of application varied. Treatments were pendimethalin EC or ME applied as either an aqueous solution in water, or impregnated on fertilizer (10-10-10) that was applied at $280 \mathrm{~kg} \mathrm{ha}^{-1}$ with a Gandy fertilizer applicator (Figure 4). All herbicide spray treatments were made with a $\mathrm{CO}_{2}$-pressurized backpack sprayer using Teejet 11002 flat fan nozzles, which delivered $140 \mathrm{~L} / \mathrm{ha}$ of water at $130 \mathrm{kPa}$. For the fertilizer treatment, pendimethalin EC or ME at $1.1 \mathrm{~kg}$ active ingredient ha ${ }^{-1}$ was impregnated on fertilizer using a $\mathrm{CO}_{2}$-pressurized sprayer with a Teejet 8002 flat fan nozzle at $130 \mathrm{kPa}$. Fertilizer was rotated at a constant speed of 12 meter minute ${ }^{-1}$ using a rotating steel drum. The drum freely rotated on a twin roller rod system set at a $30^{\circ}$ angle, powered by an electric motor, with speed adjusted by a rheostat (Figure 5). 


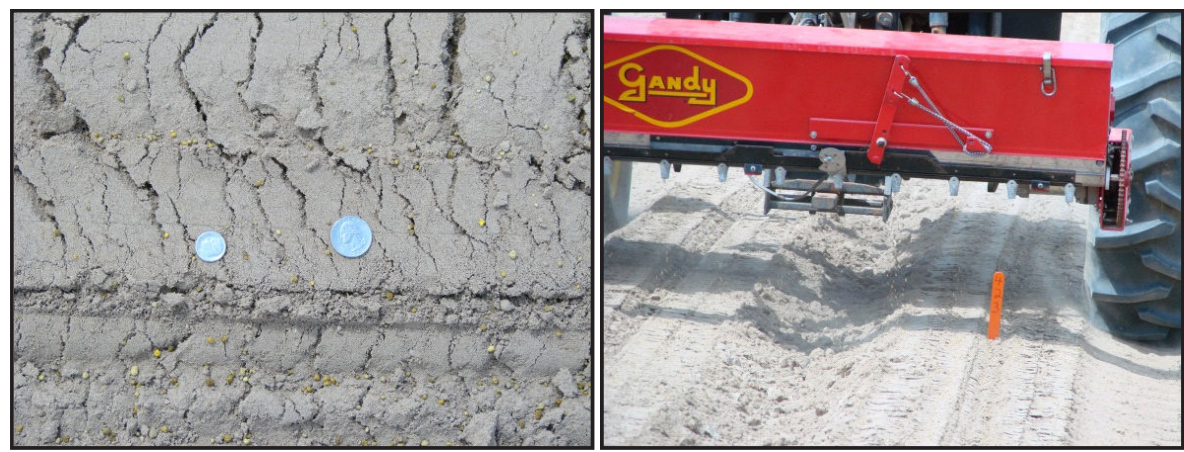

Figure 4. Pendimethalin impregnated fertilizer treatment on soil surface (left) and application (right).

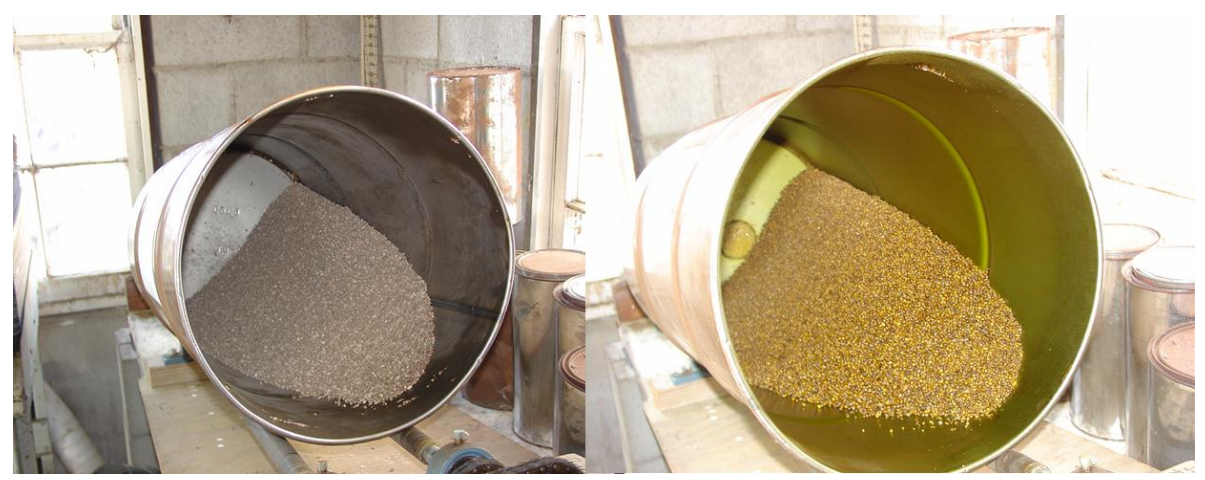

Figure 5. Fertilizer prior to (left) and after (right) treatment with pendimethalin formulation Prowl 3.3EC.

All plots received the same fertilizer rates to ensure no variability for fertility. Plots were then irrigated the day after treatments were applied. Treatments were made at four different application timings, at planting prior to plant emergence (PRE), at seedling emergence (AE), to $3^{\text {rd }}$ leaf, or to $6^{\text {th }}$ leaf cotton. A non-treated control was included for comparison for a total of 17 treatments. All plots were maintained weed free by hand pulling weed escapes and treatments with glyphosate. Other cultural and pest management practices were based upon recommendations by the Georgia Cooperative Extension Service. Supplemental overhead sprinkler irrigation was applied as needed. Cotton injury ratings were evaluated after applications using a scale of 0 (no injury) to $100 \%$ (plant death) [8]. Cotton height measures were made up to five times in 2005, 2006 and 2007. Both rows of each plot were harvested with a spindle picker, and seed cotton yield was quantified. Data were subjected to mixed model ANOVA using Proc Mixed in SAS 9.1, with random effects of years and replications. Mean separation was determined using the PDMIX800 macro. Regression analysis was performed using Sigmaplot 12 nonlinear regression. The intent was to determine if the response could be described by using the exponential growth, Stirling Model. 


$$
y=y 0+\frac{\left.\mathrm{a}\left(e^{\mathrm{bx}}\right)-1\right]}{\mathrm{b}}
$$

Where $y$ is the response variable of treatment, $y 0$ is the value of the response variable (y) when $X$ is equal to zero, $a$ is the rate of growth, and $X$ is time in days. Data for growth were analyzed by ANOVA under the general linear models procedure and used mean separation of $95 \%$ asymptotic confidence intervals for comparison of parameter estimates.

\subsection{Laboratory studies}

Fertilizer samples were taken prior to and after treatment with EC and ME pendimethalin. Samples were viewed at $\times 125$ and $\times 200$ magnification with a light microscope. Images were captured with a digital camera with image analysis software. Figure 6 notes the smooth surface for the EC formulations verses the course texture of the ME formulation alone and when impregnated on fertilizer.

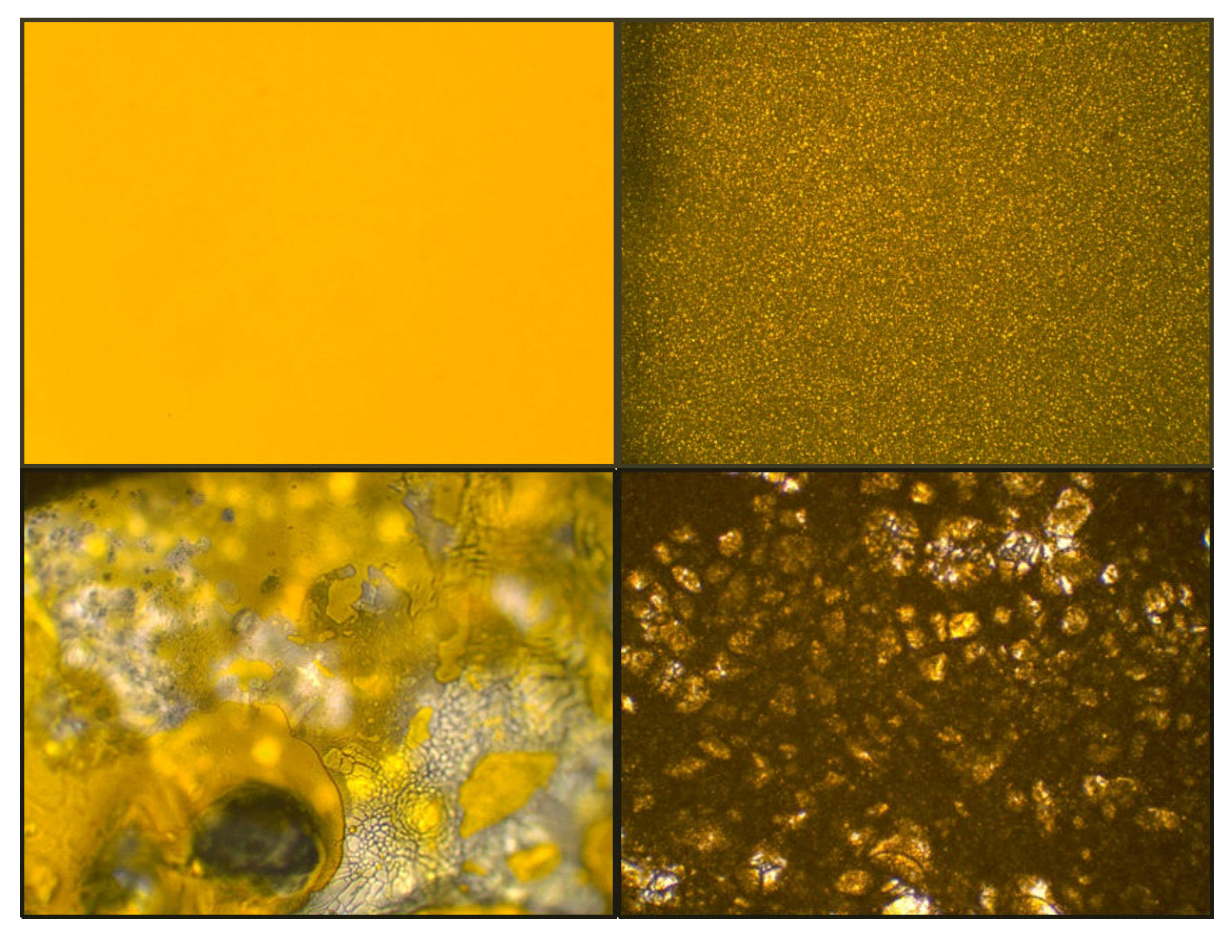

Figure 6. Pendimethalin EC (top left) and ME (top right) formulations alone ( $\mathrm{x} 125$ light microscope magnification), and EC (bottom left) and ME (bottom right) impregnated on fertilizers (x200). 


\section{Cotton response}

There were significant formulation by application method, application method by timing, and formulation by timing interactions for cotton plant injury and cotton yield. Since the nontreated control had no associated timing effects and did not differ significantly in cotton yield or injury from the PRE applications (Table 2), comparisons of injury and yield included only the treated plots to simplify the model.

\subsection{Cotton injury}

Spray applications of pendimethalin EC resulted in greater crop injury (27\%) than when pendimethalin EC was applied with fertilizer (12\%) or both application methods of pendimethalin ME $(\leq 12 \%)$ (Table 2). Pendimethalin on fertilizer applied at the $3^{\text {rd }}$ leaf stage and both application methods applied PRE or the $6^{\text {th }}$ leaf stage of cotton had lower levels $(\leq 7 \%)$ of cotton injury than all other treatments. For PRE applications, pendimethalin injury in the form of stunting, leaf curl, leathery cotyledons, swollen hypocotyl, and intense green color were observed, but this did not affect plant establishment, confirming previous results [14]. There was similar and significant injury when pendimethalin (Figure 7) was applied as cotton emerged (AE) with both the fertilizer (27\%) and spray (42\%) application and when sprayed at the $3^{\text {rd }}$ leaf stage $(27 \%)$. Previous reports of cotton injury resulting from a topical application of pendimethalin $\mathrm{ME}$ at the $4^{\text {th }}$ leaf growth stage $(\leq 20 \%)$ was lower than that from pendimentalin EC ( $\leq 33 \%)$ [7]. When averaged over application method, there was minimal cotton injury when either pendimethalin formulation was applied PRE or at the $6^{\text {th }}$ leaf stage. Greatest injury occurred when pendimethalin EC was applied AE (47\%). At both the AE and $3^{\text {rd }}$ leaf stage timings, pendimethalin ME caused less cotton injury than pendimethalin EC.

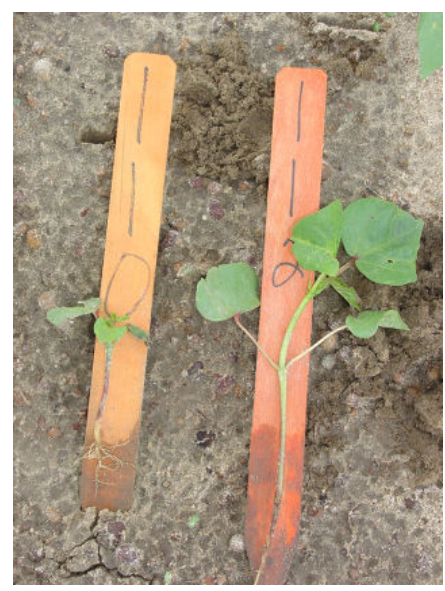

Figure 7. Cotton injury from pendimethalin EC (110) as compared to pendimethalin ME (112). Both rates were $1.1 \mathrm{~kg}$ active ingredient/ha at cotton emergence (AE) applied. 


\begin{tabular}{|c|c|c|c|c|c|c|}
\hline \multirow[b]{2}{*}{ Formulation } & \multirow[b]{2}{*}{ Application } & \multirow[b]{2}{*}{ Timing } & \multicolumn{3}{|c|}{ Injury } & \multirow[t]{2}{*}{ LSD $^{a}$} \\
\hline & & & & $\%$ & - & \\
\hline \multirow[t]{2}{*}{ Pendimethalin $\mathrm{EC}^{\mathrm{bc}}$} & Spray & & 27 & $a^{d}$ & $(4)^{d}$ & 7 \\
\hline & Fertilizer $^{f}$ & & 12 & $b$ & (4) & \\
\hline \multirow[t]{10}{*}{ Pendimethalin ME } & Spray & & 12 & $b$ & (4) & \\
\hline & Fertilizer & & 8 & $b$ & (4) & \\
\hline & Spray & PRE & 7 & c & (5) & 10 \\
\hline & Fertilizer & PRE & 6 & c & (5) & \\
\hline & Spray & $A E$ & 42 & a & $(5)$ & \\
\hline & Fertilizer & $A E$ & 27 & $b$ & (5) & \\
\hline & Spray & $3 L F$ & 27 & $b$ & (5) & \\
\hline & Fertilizer & $3 L F$ & 5 & $c$ & (5) & \\
\hline & Spray & $6 \mathrm{LF}$ & 1 & $c$ & $(5)$ & \\
\hline & Fertilizer & $6 \mathrm{LF}$ & 3 & c & (5) & \\
\hline Pendimethalin EC & & PRE & 7 & $c$ & (5) & 10 \\
\hline Pendimethalin ME & & PRE & 6 & $c$ & (5) & \\
\hline Pendimethalin EC & & $\mathrm{AE}$ & 47 & a & (5) & \\
\hline Pendimethalin ME & & $\mathrm{AE}$ & 21 & $b$ & (5) & \\
\hline Pendimethalin EC & & $3 L F$ & 24 & $b$ & $(5)$ & \\
\hline Pendimethalin ME & & $3 L F$ & 8 & $c$ & (5) & \\
\hline Pendimethalin EC & & $6 \mathrm{LF}$ & 3 & $c$ & (5) & \\
\hline Pendimethalin ME & & $6 \mathrm{LF}$ & 7 & $c$ & (5) & \\
\hline
\end{tabular}

aBecause proc Mixed measures pair-wise differences, multiple LSDs may be obtained. In these cases, the LSD ( $a=0.05$ ] included is the mean LSD for all treatments.

bPendimethalin rates were $1.1 \mathrm{~kg}$ ai/ha for the $\mathrm{EC}$ and $\mathrm{ME}$ formulations.

c Abbreviations: EC, emulsifiable concentrate $(0.41 \mathrm{~kg}$ ai/L); $M E$, microencapsulated $(0.47 \mathrm{~kg}$ ai/L); PRE, prior to plant emergence; $A E$, at seedling emergence; $3 L F$, to $3^{\text {rd }}$ leaf cotton; $6 L F, 6^{\text {th }}$ leaf cotton

${ }^{d}$ Means within a variable followed by the same letter are not significantly different using Fisher's protected $\operatorname{LSD}_{(\mathrm{P}=0.05)}$. Standard error of the mean for that treatment enclosed in ().

${ }^{\mathrm{f}}$ Fertilizer [10 -10-10] rate was $280 \mathrm{~kg} / \mathrm{ha}$, with all plots equally treated. Pendimethalin EC and ME were spray impregnated.

Table 2. Interaction effects between pendimethalin formulation, application method, and application timing for injury in conventional tillage cotton. 


\subsection{Cotton height}

There were no significant effects on cotton height during the year regardless of the pendimethalin formulation or application type (Figures 8 to 10). The pendimethalin EC formulation (Figure 8) and spray application (Figure 9) did reduce height at 45 days after planting, but this was not significant and was not observed by 75 days after planting for either scenario. Cotton height was reflected in the injury for the timing of application (Figure 10). No differences were noted in height for the $6^{\text {th }}$ leaf treatment timings. While there was cotton injury and height reduction when pendimethalin EC was spray applied at the AE or $3^{\text {rd }}$ leaf timings, cotton recovered and height measures were equivalent by the end of the season. Utilizing exponential growth Stirling model, all curves converged with the analysis at no greater than 14 iterations (data not presented) with no differences for parameter estimates (Tables 3, 4 and 5). The long growing season in tandem with cotton's physiological ability to compensate for early season injury essentially explains why growth models can be effectively used to predict the lack of net negative effects from early season injury from pendimethalin applications.

\begin{tabular}{|c|c|c|c|c|c|c|}
\hline \multirow[b]{2}{*}{ Herbicide } & \multicolumn{6}{|c|}{ Rate of cotton growth } \\
\hline & $a^{c}$ & & $95 \% \mathrm{CL}$ & b & & $95 \% \mathrm{CL}$ \\
\hline Pendimethalin EC & 0.0537 & a & \pm 0.0179 & 0.0513 & a & \pm 0.00555 \\
\hline Pendimethalin ME & 0.0516 & a & \pm 0.0173 & 0.0514 & a & \pm 0.0056 \\
\hline Nontreated & 0.0669 & $\mathrm{a}$ & \pm 0.0558 & 0.0471 & a & \pm 0.0140 \\
\hline
\end{tabular}

aEach herbicide for first-order rate constants for each column followed by the same letter are not significantly different according to Fisher's protected LSD test $(P \leq 0.05)$. General linear models procedures were used for mean separation with $95 \%$ asymptotic confidence intervals.

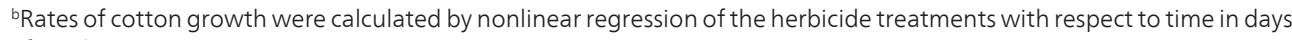
after planting.

'Abbreviations: $a$, rate of cotton growth; $C L$, confidence limit.

Table 3. Rate of cotton growth (a) as a response to pendimethalin formulation. ${ }^{\text {a }}$

\begin{tabular}{|c|c|c|c|c|c|c|}
\hline \multirow[b]{2}{*}{ Application method } & \multicolumn{6}{|c|}{ Rate of cotton growth ${ }^{b}$} \\
\hline & $a^{c}$ & & $95 \% \mathrm{CL}$ & b & & $95 \% \mathrm{CL}$ \\
\hline Fertilizer & 0.0653 & $a$ & \pm 0.0208 & 0.0485 & a & \pm 0.0053 \\
\hline Spray & 0.0418 & a & \pm 0.0144 & 0.0545 & $a$ & \pm 0.0057 \\
\hline Nontreated & 0.0689 & a & \pm 0.0594 & 0.0463 & a & \pm 0.0145 \\
\hline
\end{tabular}

aEach application method for first-order rate constants for each column followed by the same letter are not significantly different according to Fisher's protected LSD test $(P \leq 0.05)$. General linear models procedures were used for mean separation with $95 \%$ asymptotic confidence intervals.

${ }^{\text {b}}$ Rates of cotton growth were calculated by nonlinear regression of the herbicide treatments with respect to time in days after planting. 
'Abbreviations: a, rate of cotton growth; CL, confidence limit.

Table 4. Rate of cotton growth (a) as a response to method of pendimethalin application. ${ }^{\text {a }}$

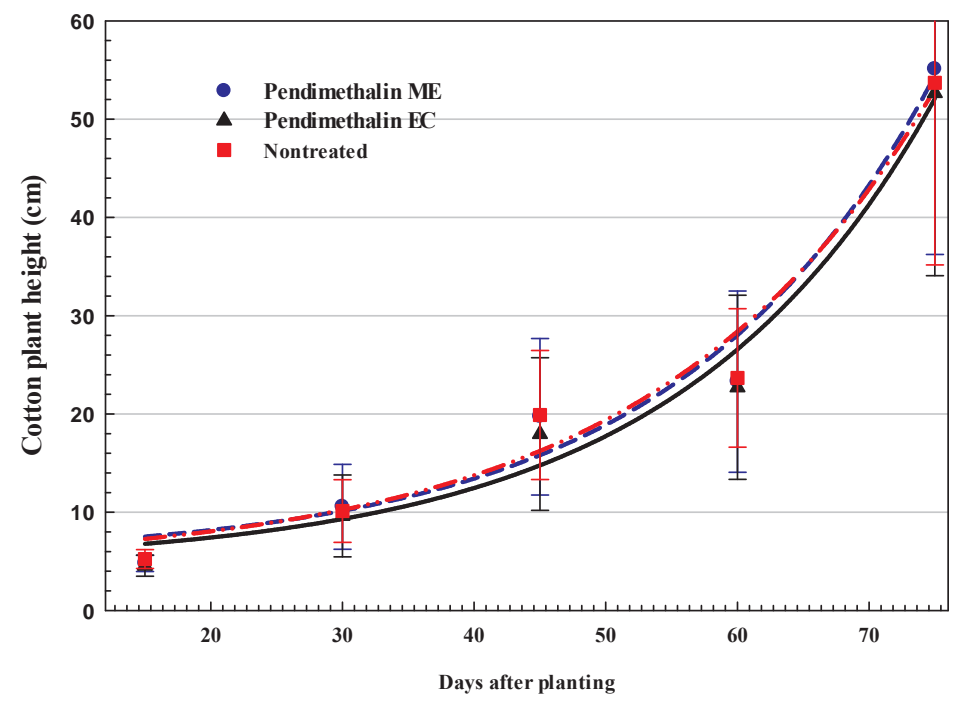

Figure 8. Cotton growth response as affected by pendimethalin formulation. The line represents the first-order regression equation. Data points are the means of replications with bars indicating the standard error of the mean:

Fertilizer applied $y=6.31+\frac{0.0537\left[\left(e^{0.05137 x)}-1\right]\right.}{0.05137} \mathrm{P}<0.0001$

Spray applied $y=5.62+\frac{0.0516\left[\left(e^{0.0514 x}\right)-1\right]}{0.0514} \mathrm{P}<0.0001$

Nontreated $y=5.83+\frac{0.0669\left[\left(e^{0.0471 x}\right)-1\right]}{0.0471} \mathrm{P}<0.0001$

\begin{tabular}{lcccccc}
\hline \multicolumn{7}{c}{ Rate of cotton growth } \\
\hline Application timing & $\mathbf{a}^{\mathbf{c}}$ & & $\mathbf{9 5 \%} \mathbf{C L}$ & $\mathbf{b}$ & $\mathbf{9 5 \%} \mathbf{C L}$ \\
\hline Preemergence & 0.1104 & $\mathrm{a}$ & \pm 0.0621 & 0.0395 & $\mathrm{a}$ & \pm 0.0067 \\
\hline At cotton emergence & 0.0649 & $\mathrm{a}$ & \pm 0.0384 & 0.0488 & $\mathrm{a}$ & \pm 0.0099 \\
\hline $3^{\text {rd }}$ leaf cotton & 0.0550 & $\mathrm{a}$ & \pm 0.0372 & 0.0512 & $\mathrm{a}$ & \pm 0.0112 \\
\hline $6^{\text {th }}$ leaf cotton & 0.0415 & $\mathrm{a}$ & \pm 0.0319 & 0.0559 & $\mathrm{a}$ & \pm 0.0126 \\
\hline Nontreated & 0.0689 & $\mathrm{a}$ & \pm 0.0594 & 0.0463 & $\mathrm{a}$ & \pm 0.0145 \\
\hline
\end{tabular}

aEach application timing for first-order rate constants for each column followed by the same letter are not significantly different according to Fisher's protected LSD test $(P \leq 0.05)$. General linear models procedures were used for mean separation with $95 \%$ asymptotic confidence intervals. 


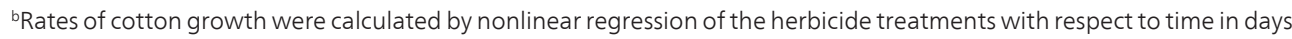
after planting.

'Abbreviations: $a$, rate of cotton growth; $C L$, confidence limit.

Table 5. Rate of cotton growth (a) as a response to timing of pendimethalin application. ${ }^{\text {a }}$

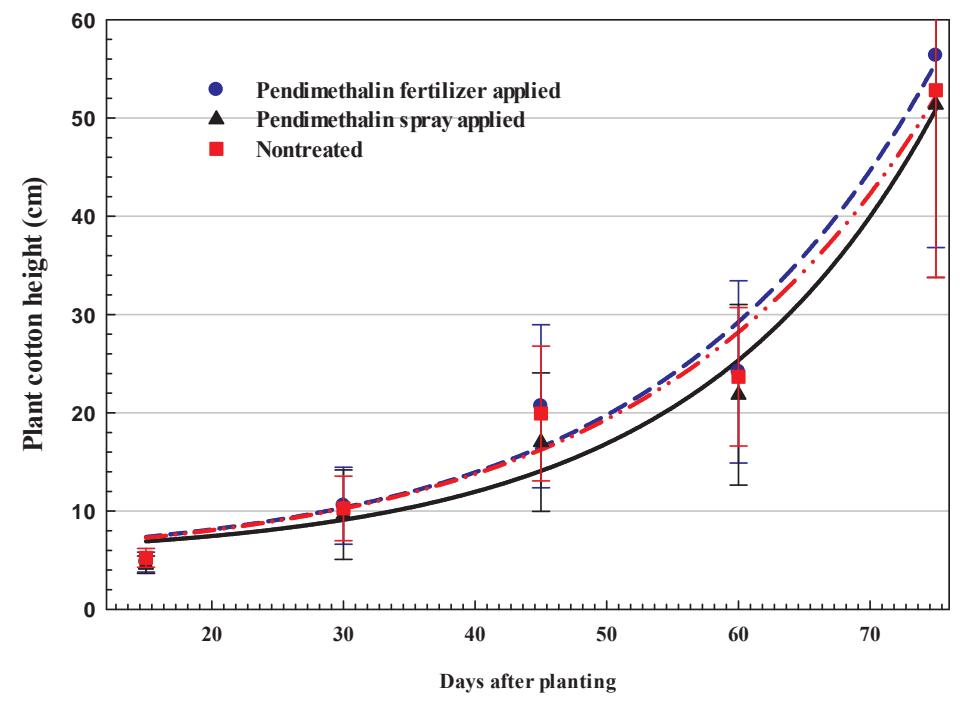

Figure 9. Cotton growth response as affected by application method. The line represents the first-order regression equation. Data points are the means of replications with bars indicating the standard error of the mean:

Pendimethalin ME $y=5.93+\frac{0.0653\left[\left(e^{0.0485 x}\right)-1\right]}{0.0485} \mathrm{P}<0.0001$

Pendimethalin EC $y=5.95+\frac{0.0418\left[\left(e^{0.0545 x}\right)-1\right]}{0.0545} \mathrm{P}<0.0001$

Nontreated $y=5.78+\frac{0.0689\left[\left(e^{0.0463 x}\right)-1\right]}{0.0463} \mathrm{P}<0.0001$

\subsection{Cotton yield}

Cotton yields reflected the trends initially revealed with cotton injury. Pendimethalin EC spray applied $\left(3,610 \mathrm{~kg} \mathrm{ha}^{-1}\right)$ had lower cotton yield than pendimethalin EC applied on fertilizer $\left(4,010 \mathrm{~kg} \mathrm{ha}^{-1}\right)$ and both pendimethalin ME treatments $\left(\geq 4,000 \mathrm{~kg} \mathrm{ha}^{-1}\right)$ (Table 6$)$. The treatments that caused the greatest cotton injury for application method by timing interaction had the lowest yields, included both spray AE and $3^{\text {rd }}$ leaf stage of cotton applications. Application timing of pendimethalin on fertilizer did not affect cotton yield. When averaged over application method, cotton yield for the pendimethalin ME treatments had equivalent cotton yields 
across all application timings. Only pendimethalin EC applied AE or $3^{\text {rd }}$ leaf stage cotton lower yields compared to the typical PRE use-pattern.

None of the PRE or $6^{\text {th }}$ leaf application treatments displayed crop injury, significant decreased growth, or significant yield loss. The $\mathrm{AE}$ and $3^{\text {rd }}$ leaf application treatments resulted in significant cotton crop injury and decreased yield, with pendimethalin EC treatments having greater injury than the pendimethalin ME, with spray applications exhibiting more injury than the fertilizer-applied treatments. The fertilizer application of pendimethalin at $3^{\text {rd }}$ leaf did not significantly enhance crop injury, but did enhance injury at the AE application timing. Based on injury, subsequent height, and final yield measurements, pendimethalin ME caused less injury than pendimethalin EC, and fertilizer application of both formulations was less injurious than spray application. The AE application timing was prone to greater injury by any formulation or application method and should be avoided. The $3^{\text {rd }}$ leaf appears to be more prone to spray injury than fertilizer injury.

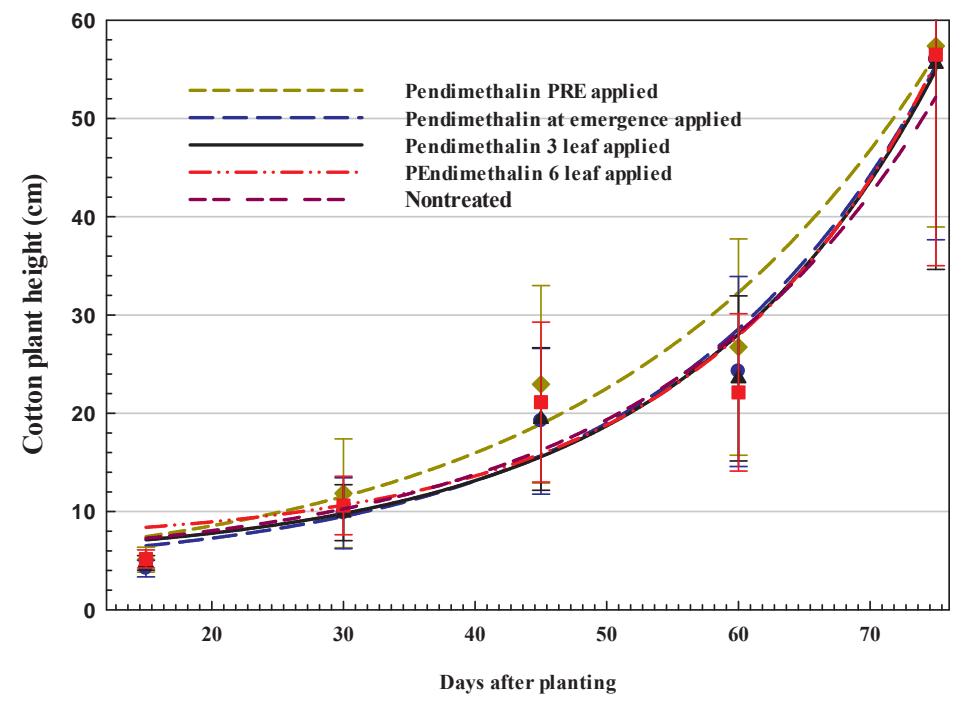

Figure 10. Cotton growth response as affected by application timing. The line represents the first-order regression equation. Data points are the means of replications with bars indicating the standard error of the mean:

Pendimethalin PRE applied $y=5.18+\frac{0.1104\left[\left(e^{0.0395 x}\right)-1\right]}{0.0395} \mathrm{P}<0.0001$

Pendimethalin AE applied $y=5.08+\frac{0.0649\left[\left(e^{0.0488 x}\right)-1\right]}{0.0545} \mathrm{P}<0.0001$ 
Pendmethalin 3 leaf applied $y=5.87+\frac{0.0550\left[\left(e^{0.0512 x}\right)-1\right]}{0.0512} \mathrm{P}<0.0001$

Pendimethalin 6 leaf applied $y=7.42+\frac{0.0450\left[\left(e^{0.00559 x}\right)-1\right]}{0.0559} \mathrm{P}<0.0001$

Nontreated $y=5.78+\frac{0.0689\left[\left(e^{0.0463 x}\right)-1\right]}{0.0463} \mathrm{P}<0.0001$

\begin{tabular}{|c|c|c|c|c|c|c|}
\hline \multirow{3}{*}{$\frac{\text { Formulation }}{\text { Pendimethalin EC }}$} & \multirow{3}{*}{$\begin{array}{c}\text { Application } \\
\text { Spray }\end{array}$} & \multirow{3}{*}{ Timing } & \multicolumn{3}{|c|}{ Yield } & \multirow{3}{*}{$\begin{array}{l}\text { LSD } \\
252\end{array}$} \\
\hline & & & 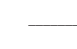 & $-\mathrm{kg}$ & 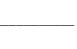 & \\
\hline & & & 3610 & $b$ & $(145)$ & \\
\hline & Fertilizer & & 4010 & a & (149) & \\
\hline \multirow[t]{10}{*}{ Pendimethalin ME } & Spray & & 4000 & a & (149) & \\
\hline & Fertilizer & & 4230 & $\mathrm{a}$ & (154) & \\
\hline & Spray & PRE & 4130 & $\mathrm{a}$ & $(176)$ & 370 \\
\hline & Fertilizer & PRE & 4260 & $\mathrm{a}$ & $(180)$ & \\
\hline & Spray & $\mathrm{AE}$ & 3570 & $b$ & $(172)$ & \\
\hline & Fertilizer & $\mathrm{AE}$ & 4050 & a & $(175)$ & \\
\hline & Spray & $3 \mathrm{LF}$ & 3450 & $b$ & $(170)$ & \\
\hline & Fertilizer & $3 \mathrm{LF}$ & 4070 & a & $(176)$ & \\
\hline & Spray & $6 \mathrm{LF}$ & 4080 & $\mathrm{a}$ & (188) & \\
\hline & Fertilizer & $6 \mathrm{LF}$ & 4110 & a & $(182)$ & \\
\hline Pendimethalin EC & & PRE & 4140 & a & $(181)$ & 369 \\
\hline Pendimethalin ME & & PRE & 4250 & $\mathrm{a}$ & (178) & \\
\hline Pendimethalin EC & & $\mathrm{AE}$ & 3630 & $\mathrm{bc}$ & $(169)$ & \\
\hline Pendimethalin ME & & $\mathrm{AE}$ & 3980 & $a b$ & $(175)$ & \\
\hline Pendimethalin EC & & $3 \mathrm{LF}$ & 3510 & $c$ & (169) & \\
\hline Pendimethalin ME & & $3 \mathrm{LF}$ & 4000 & $a b$ & $(174)$ & \\
\hline Pendimethalin EC & & $6 \mathrm{LF}$ & 3960 & $a b$ & (185) & \\
\hline Pendimethalin ME & & $6 \mathrm{LF}$ & 4230 & $a$ & (185) & \\
\hline
\end{tabular}

aBecause proc Mixed measures pair-wise differences, multiple LSDs may be obtained. In these cases, the LSD ( $a=0.05$ ) included is the mean LSD for all treatments.

bPendimethalin rates were $1.1 \mathrm{~kg}$ ai/ha for the EC and ME formulations. 
c Abbreviations: EC, emulsifiable concentrate (0.41 kg ai/L); ME, microencapsulated (0.47 kg ai/L); PRE, prior to plant emergence; $A E$, at seedling emergence; 3LF, to 3-leaf cotton; 6LF, 6-leaf cotton

${ }^{d}$ Means within a variable followed by the same letter are not significantly different using Fisher's protected $\operatorname{LSD}_{(\mathrm{P}=0.05)}$. Standard error of the mean for that treatment enclosed in ().

${ }^{\mathrm{f} F e r t i l i z e r}$ (10-10-10) rate was $280 \mathrm{~kg} / \mathrm{ha}$, with all plots equally treated. Pendimethalin EC and ME were spray impregnated.

Table 6. Interaction effects between pendimethalin formulation, application method, and application timing for yield in conventional tillage cotton.

\section{Discussion}

Comparing the EC to ME pendimethalin formulations, when either spray or fertilizer impregnated applied, indicated the ME formulation consistently reduced cotton injury. The reason for the reduced cotton injury from the $\mathrm{ME}$ as compared to the EC-pendimethalin formulation is due to the microencapsulation. This has been observed with another ME formulated herbicide, alachlor [29]. While pendimethalin has lower volatilization than other dinitroanaline herbicides such as trifluralin [21], the ME formulation decreases volatilization and provides extended activity. As previously noted, pendimethalin half-lives of 74 to 114 days in soil have been reported [30], surface applied half-lives of 4 to 6 days can occur due to volatilization, photo-chemical, and other degradation processes with EC formulation [21]. By utilizing the ME formulation, supplementing, or even delaying pendimethalin application to in-season timings impregnated on fertilizer, growers could extend residual weed control until cotton can canopy and suppress weed growth. Our recommendation would be to utilize pendimethalin as a PRE application followed by an in-season application impregnated on prilled fertilizers to extend weed control. Total seasonal pendimethalin applications in cotton are up to $2.24 \mathrm{~kg} \mathrm{ha}^{-1}$. Cotton fertility recommendations for the southeast include in-season nitrogen applications which could be pendimethalin impregnated. Given advanced global positioning systems (GPS) used for accurate fertilizer applications, even greater precision for pesticide applications can now be achieved in tandem with these advanced technologies. These data indicate that cotton growers can successfully incorporate in-season pendimethalin application into their cotton production programs with minimal potential for cotton injury, while supplementing weed control with a residual herbicide.

\section{Author details}

Timothy Grey $^{1^{*}}$ and Theodore Webster ${ }^{2}$

*Address all correspondence to: tgrey@uga.edu

1 Crop and Soil Sciences Department, University of Georgia, Tifton Georgia, USA

2 Crop Protection and Management Research Unit, USDA-ARS, Tifton Georgia, USA 


\section{References}

[1] AnonymousConservation Technology Information Center. (2005). National crop residue management survey. Available at www.ctic.purdue.edu/CTIC/CRM.htmlaccessed 12 Mar. 2009). CTIC, West Lafayette, IN. online].

[2] Byrd JrJ.D. and A.C. York. (1987). Annual grass control in cotton with fluazifop, sethoxydim, and selected dinitroaniline herbicides. Weed Sci. , 35, 388-394.

[3] Culpepper, A. S. (2007). Cotton weed control. Georgia pest control handbook. Coop. Ext. Serv. The Univ. of Georgia College of Agr. and Environ. Sci., Athens, GA.

[4] Culpepper, A. S, Flanders, J. T, York, A. C, \& Webster, T. M. (2004). Tropical spiderwort (Commelina benghalensis) control in glyphosate-resistant cotton. Weed Technology , 18, 432-436.

[5] Culpepper, A. S, Grey, T. L, Vencill, W. K, Kichler, J. M, Webster, T. M, Brown, S. M, York, A. C, Davis, J. W, \& Hanna, W. M. (2006). Glyphosate-resistant Palmer amaranth (Amaranthus palmeri) confirmed in Georgia. Weed Sci. DOI:WS-06-001R.1., 54, 620-626.

[6] Devine, M. D, Duke, S. O, \& Fedtke, C. (1993). Physiology of Herbicide Action. Englewood Cliffs, New Jersey: Prentice Hall. 441 p.

[7] Dodds, D. M, Reynolds, D. B, Huff, J. A, \& Irby, J. T. (2010). Effect of pendimethalin formulation and application rate on cotton fruit partitioning. Weed Technology , 24, 77-84.

[8] Frans, R. E, Talbert, R, Marx, D, \& Crowley, H. (1986). Experiment design and techniques for measuring and analyzing plant responses to weed control practices. In D. Camper, ed. Research Methods in Weed Science. 3rd ed. Champaign, IL: Southern Weed Sci. Soc. , 29-46.

[9] Gaston, L. A, Boquet, D. J, \& Bosch, M. A. (2003). Pendimethalin wash-off from cover crop residues and degradation in a loess soil. Communications in Soil Sci. and Plant Analysis DOI:10.1081/CSS-120024783 , 34, 2515-2527.

[10] Gordon, J. A, \& Green, C. J. (1999). Comparative field and greenhouse studies of trifluralin and pendimethalin on cotton growth, development, and nutrient uptake. In Proc. Beltwide Cotton Conf., Orlando, FL, Natl. Cotton Counc. Am. Memphis, TN., 536-539.

[11] Grey, T. L, Webster, T. M, \& Culpepper, A. S. (2008). Weed control as affected by pendimethalin timing and application method in conservation tillage cotton (Gossypium hirsutum). J. Cotton Sci. , 12, 318-324. 
[12] Hatzinikolaou, A. S, Eleftherohorinos, I. G, \& Vasilakoglou, I. B. (2004). Influence of formulation on the activity and persistence of pendimethalin. Weed Technol , 18, 397-403.

[13] Keeling, J. W, \& Abernathy, J. R. (1989). Response of cotton (Gossypium hirsutum) to repeated application of dinitroaniline herbicides. Weed Technol. , 3, 527-530.

[14] Keeling, J. W, Dotray, P. A, \& Abernathy, J. R. (1996). Effects of repeated applications of trifluralin and pendimethalin on cotton (Gossypium hirsutum). Weed Technol. , 10, 295-298.

[15] Martens, A. R, Burnside, O. C, \& Cramer, G. L. (1978). Compatibility and phytotoxicity of herbicide-fertilizer. Agron. J. , 70, 1089-1098.

[16] Mueller, T. C, Mitchell, P. D, Yound, B. G, \& Culpepper, A. S. (2005). Proactive Versus Reactive Management of glyphosate-resistant or-tolerant weeds. Weed Technol. , 19, 924-933.

[17] National Agricultural Statistics Service (NASS) (2010). National Agricultural Statistics Service U.S. Dept. of Agri.. Published Estimates Database. NASS-USDA, Washington, DC. http://www.nass.usda.gov/Statistics_by_Subject/Environmental/ index.asp

[18] Norsworthy, J. K, Smith, K. L, Steckel, L. E, \& Koger, C. H. (2009). Weed seed contamination of cotton gin trash. Weed Technol. , 23, 574-580.

[19] Parochetti, J. V, \& Dec, G. W. Jr. (1978). Photodecomposition of eleven dinitroaniline herbicides. Weed Sci. , 26, 153-156.

[20] Rabaey, T. L, \& Harvey, R. G. (1994). Efficacy of corn (Zea mays) herbicides applied at reduced rates impregnated in dry fertilizer. Weed Technol. , 8, 830-835.

[21] Savage, K. E, \& Jordan, T. N. (1980). Persistence of three dinitroaniline herbicides on the soil surface. Weed Sci. , 28, 105-110.

[22] Senseman, S. A. (2007). Weed Science Society of America Herbicide Handbook, $9^{\text {th }}$ ed. Lawrence, KS. , 283-285.

[23] Shaner, D. L. (2000). The impact of glyphosate-tolerant crops on the use of other herbicides on resistance management. Pest Manag. Sci. , 56, 320-326.

[24] Shaner, D. L. (2000). The impact of glyphosate-tolerant crops on the use of other herbicides on resistance management. Pest Manag. Sci. , 56, 320-326.

[25] Shaner, D. L, Tecle, B, \& Johnson, D. H. (1998). Mechanisms of selectivity of pendimethalin and trifluralin in cotton (Gossypium hirsutum) and weeds. In Proc. Beltwide Cotton Conf., San Diego, CA, Natl. Cotton Counc. Am. Memphis, TN., 1399-51402. 
[26] Sosnoskie, L. M, Kichler, J. M, Wallace, R. D, \& Culpepper, A. S. (2011). Multiple resistance in Palmer amaranth to glyphosate and pyrithiobac confirmed in Georgia. Weed Sci. , 59, 321-325.

[27] Sosnoskie, L. M, Webster, T. M, \& Culpepper, A. S. (2012). Estimates of Palmer amaranth (Amaranthus palmeri) seedbank longevity and potential post-dispersal herbivory. Weed Sci. (submitted).

[28] Sosnoskie, L. M, Webster, T. M, Dales, D, Rains, G. C, Grey, T. L, \& Culpepper, A. S. (2009). Pollen grain size, density, and settling velocity for Palmer amaranth (Amaranthus palmeri). Weed Sci. Walker, A. and W. Bond. 1977. Persistence of the herbicide AC92,553,N-(1-ethylpropyl)-2,6 dinitro-3,4-xylidine in soils. Pestic. Sci. 8:359-365., 57, 404-409.

[29] Vasilakoglou, I. B, \& Eleftherohorinos, I. G. (1997). Activity, adsorption, mobility, efficacy, and persistence of alachlor as influenced by formulation. Weed Sci. , 45, 579-585.

[30] Vencill, W. K. (2002). Weed Science Society of America Herbicide Handbook, 8th ed. Lawrence, KS. , 231-234.

[31] Vencill, W. K, Grey, T. L, Culpepper, A. S, Gaines, C, \& Westra, R. (2008). Herbicideresistance in the Amaranthaceae. J. Plant Dis. Prot. Special Iss. XXI: , 41-44.

[32] Weber, J. B. (1990). Behavior of dinitroanaline herbicides in soils. Weed Technol. , 4, 394-406.

[33] Webster, T. M, \& Nichols, R. L. (2012). Changes in the prevalence of weed species in the major agronomic crops of the Southern United States: 1994/1995 to 2008/2009. Weed Sci. , 60, 145-157.

[34] Webster, T. M, \& Sosnoskie, L. M. (2010). The loss of glyphosate efficacy: a changing weed spectrum in Georgia cotton. Weed Sci. , 58, 73-79.

[35] Wilcut, J. W, Wehtje, G. R, \& Hicks, T. V. (1990). Evaluation of herbicide systems in minimum-and conventional tillage peanuts (Arachis hypogaea). Weed Sci. , 38, 243-248.

[36] Wilcut, J. W, Patterson, M. G, Wehtje, G. R, \& Whitwell, T. (1988). Efficacy and economics of pendimethalin herbicide combinations for weed control in cotton (Gossypium hirsutum). App. Ag. Res. , 3, 203-208.

[37] Wilcut, J. W, Coble, H. D, York, A. C, \& Monks, D. W. (1996). The niche for herbicideresistant crops in U.S. agriculture. In S.O. Duke (ed.) Herbicide-resistant crops: Agricultural, environmental, economic, regulatory, and technical aspects. CRC Press, Boca Raton, FL., 213-230.

[38] Wise, A. M, Grey, T. L, Prostko, E. P, Vencill, W. K, \& Webster, T. M. Establishing the geographical distribution and level of acetolactate synthase resistance of Palmer 
amaranth (Amaranthus palmeri) accessions in Georgia. Weed Tech. Weed Technol. , 23, 214-220. 